\title{
Optimization of Pre-treatment Process of Cocoa Pod Husk Using Various Chemical Solvents
}

\author{
Novizar Nazir", Novelina", Efni Juita ${ }^{\#}$, Citra Amelia ${ }^{\#}$, Rizki Fatli ${ }^{\#}$ \\ ${ }^{\text {\# }}$ Faculty of Agricultural Technology, Andalas University, Indonesia, 25163 \\ E-mail:nazir_novizar@yahoo.com
}

\begin{abstract}
The purpose of research is to see the effect of type of reagent $\left(\mathrm{NaOH}, \mathrm{H}_{2} \mathrm{O}_{2}\right.$ and $\left.\mathrm{H}_{2} \mathrm{SO}_{4}\right)$ and the condition of pretreatment of cocoa pod husk towards lignin content after pre-treatment and hydrolysis, reducing sugar and total sugar content. Response Surface Method (RSM) was used to optimize process conditions of pre-treatment (delignification). Hydrolysis for all pretreated sample were carried out using $3 \% \mathrm{H}_{2} \mathrm{SO}_{4}$ with a ratio of cocoa pod husk to solvent (1:10) for 2 hours at a temperature of $110{ }^{\circ} \mathrm{C}$ using an autoclave. The chemical pre-treatment with $\mathrm{NaOH}$ was optimized by varying the concentrations of $\mathrm{NaOH}(4-8 \%$ $(w / v)$, centre point: $6 \%)$, reaction time (60-100 minutes, centre point: 80 minutes) and ratio of biomass to solvent (1:15-1:25, centre point 1:20 w/v). The optimum conditions in this study was at the concentration of $\mathrm{NaOH}\left(X_{1}\right)$ of $4 \%$ w/v, reaction time $\left(X_{2}\right)$ of 100 minutes; ratio of biomass/solvent $\left(X_{3}\right)$ of $1: 25(w / v)$. The lignin content after pre-treatment was $15.03 \%$ lignin, lignin content after hydrolysis was $19.57 \%, 11.75 \%$ of reducing sugar, and $12.78 \%$ of total sugar. The chemical pre-treatment with alkaline peroxide $\left(\mathrm{H}_{2} \mathrm{O}_{2}\right)$ was optimized by varying the concentrations of $\mathrm{H}_{2} \mathrm{O}_{2}(4-7 \% \mathrm{w} / \mathrm{v}$, centre point $5.5 \%$ (w/v)), reaction time (40-90 minutes, centre point: 65 minutes), and ratio of biomass/solvent $(4-7 \%$ w/v). The optimum conditions in this study was at the concentration of $\mathrm{H}_{2} \mathrm{O}_{2}$ concentration $\left(X_{1}\right)$ of $5.52 \%$ w/v, reaction time $\left(X_{2}\right)$ of 61.97 minutes, biomass loading in solvent $\left(X_{3}\right) 7 \%$ w/v. The lignin content after pre-treatment was $\mathbf{8 . 7 5 9}$, lignin content after hydrolysis was $25.029 \%$, $8.169 \%$ of reducing sugar, and $10.371 \%$ of total sugar. The chemical pre-treatment with $\mathrm{H}_{2} \mathrm{SO}_{4}$ was optimized by varying the concentrations of $\mathrm{H}_{2} \mathrm{SO}_{4}(0.5-1.5 \%$ w/v), reaction time (60-120 minutes, centre point: 90 minutes), and ratio of biomass to solvent (1:4-1:6 w/v, centre point 1:5 w/v). The optimum conditions was reached without hydrolysis. The optimum condition this study is at the $\mathrm{H}_{2} \mathrm{SO}_{4}$ concentration $\left(\mathrm{X}_{1}\right)$ of $1.5 \%$, reaction time $\left(\mathrm{X}_{2}\right)$ of 120 minutes, ratio of biomass/solvent $\left(\mathrm{X}_{3}\right)$ of $6 \%$. The lignin content after pre-treatment was $18.8 \%$, $15.59 \%$ of reducing sugar and $\mathbf{2 0 . 4 9 \%}$ of total sugar.
\end{abstract}

Keywords — chemical pre-treatment; bioethanol; cocoa pod; response surface method; optimization

\section{INTRODUCTION}

Lignocellulosic waste materials including various agricultural residues are the most abundant renewable source of biomass. Among them, cocoa pod is potential biomass feedstock in Indonesia since Indonesia is the third largest cocoa producer in the world. Adzimah and Asiam [1] reported that the weight of cocoa pod husk $(\mathrm{CPH})$ and cocoa beans are $14.71 \%$ and $10.93 \%$, respectively. It means is that there is a potential of about 1,067 million tons of $\mathrm{CPH}$ a year from cocoa plantation in Indonesia.

Lignocellulosic waste material can be converted into bioethanol. The process of converting lignocellulosic materials into ethanol consists of three stages: pre-treatment (delignification), saccharification or hydrolysis of cellulose into simple sugars, and the fermentation of sugars. Pretreatment aims to eliminate lignin, reduce cellulose crystallinity, and increased porosity [2].
Good pre-treatment process is a process that can reduce the use of enzymes that are expensive [3]. Cardona and Sanchez [4] states that phase is a major challenge in the conversion of lignocellulosic biomass into bioethanol. Pretreatment is one of the most expensive processes in the manufacture of bioethanol. Therefore, the efficiency of this process is expected to reduce the cost so that bioethanol can be competitive [5].

An effective and economical pre-treatment should meet the following requirements: (a) production of reactive cellulosic fibre for enzymatic attack, (b) avoiding destruction of hemicelluloses and cellulose, (c) avoiding formation of possible inhibitors for hydrolytic enzymes and fermenting microorganisms, (d) minimizing the energy demand, (e) reducing the cost of size reduction for feedstock's, (f) reducing the cost of material for construction of pretreatment reactors, (g) producing less residues, (h) consumption of little or no chemical and using a cheap chemical [6]. 
Pre-treatment can be carried out in physical, physicochemical, chemical, biological or a combination of these ways [7]. Pre-treatments in this study were conducted using chemical solvent $\left(\mathrm{NaOH}, \mathrm{H}_{2} \mathrm{O}_{2}\right.$ and $\mathrm{H}_{2} \mathrm{SO}_{4}$. while chemical hydrolysis was performed using $\mathrm{H}_{2} \mathrm{SO}_{4}$ as a solvent.

Several methods have been Introduced for various chemical pre-treatment of lignocellulosic materials with different types of solvents [8 - 14]. This study focused on chemical pre-treatment for cocoa pod husk as a potential biomass feedstock in Indonesia. The purpose of this research is to see the effect of type reagents, reaction time and conditions of pre-treatment towards lignin content in pretreated biomass, lignin content after hydrolysis reducing sugar and total sugar content of sugar hydrolyzate produced from cocoa pod husk.

\section{MATERIAL AND METHOD}

\section{A. Materials}

Cocoa pod was obtained from Cocoa Plantation at Lubuk Minturun, Padang-INDONESIA. Cocoa Pod are washed with water till clean, then cut into small pieces and then dried by solar drying until the moisture content of $\pm 10 \%$. The dried material is milled with a grinder. Cocoa pod husk was sieved to 40 mesh size.

The composition of the cocoa pod husk used in this study compared with the result from previous research is presented in Table 1.

TABLE I

THE COMPOSITION OF THE COCOA POD HUSK USED IN THIS STUDY

\begin{tabular}{|l|c|c|c|}
\hline Component & Percentage (\%) & $*(\%)$ & $* *(\%)$ \\
\hline Moisture Content & 11.04 & 14.1 & 6.75 \\
\hline Ash & 7.40 & 12.3 & 1.87 \\
\hline Crude Fiber & 49.23 & - & 53.82 \\
\hline Cellulosa & 44.69 & 35.4 & 28.78 \\
\hline Hemicellulosa & 11.15 & 37.0 & 8.70 \\
\hline Lignin & 34.82 & 14.7 & 42.90 \\
\hline Holocellulosa & 55.84 & 74.0 & - \\
\hline Pectin*** & $10.1 \pm 0.3$ & \\
\hline source*: Daud et al, [13] \\
**: Syam [15] \\
***: Vriesmanna et al [16]
\end{tabular}

Before pre-treatment, the pectin of cocoa pod husk was extracted. Pectin extraction was carried out using citric acid as a solvent [17]. CPHs was weighed as much as 100 grams, then put it into the 3 neck flask and add solvent in accordance with a variable ratio of material and solvent, namely 1: 25, with citric acid as a solvent. Extraction time of 3 hours, $\mathrm{pH} 2.5$ at a temperature of $95{ }^{\circ} \mathrm{C}$. After that the pectin-free sample is dried at the dryer cabinet at a temperature of 60-700 $\mathrm{C}$ for 12 hours. The material was stored in plastic bags at room temperature until use for pretreatment.

\section{B. Research Steps}

To produce bioethanol there are several stages which includes preparation of raw materials, pre-treatment, hydrolysis, fermentation of sugars, distillation. Figure 1 presented several stages employed in this study.

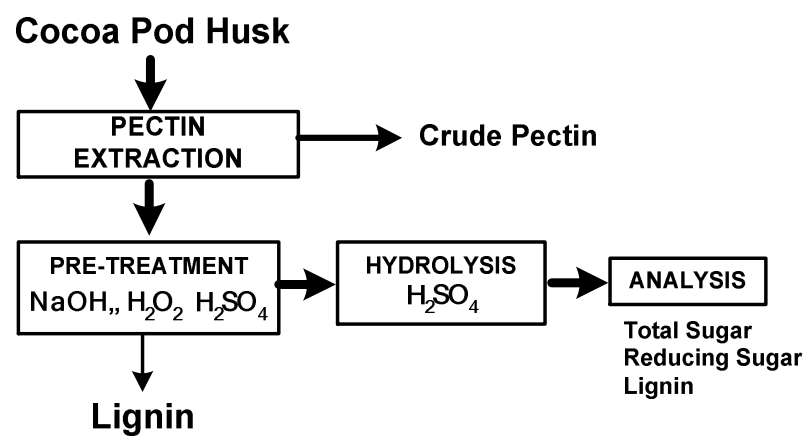

Fig. 1. Research Steps of Pre-treatment Process

\section{Pre-treatment}

The effects of pre-treatment solvent, sodium hydroxide, alkaline peroxide and sulphuric acid pre-treatment were tested. The effect of pre-treatment parameters including: solvent concentration, reaction time, and solid mass loading in solvent were evaluated. Box-Behnken methodology was used for the design and Response Surface Modelling was applied to determine the effect of the pre-treatment parameters on lignin and sugar content.

Sodium Hydroxide Pre-treatment-Pre-treatment CPHs was pretreated at $121{ }^{\circ} \mathrm{C}$ in an autoclave. Fine powder coco pod husks is put into the beaker glass. add a solution of $\mathrm{NaOH}$ at various concentration of $2.64 ; 4 ; 6,8$; and $9.36 \%$ $\mathrm{w} / \mathrm{v}$, reaction time of $45 ; 36 ; 60 ; 80 ; 100$ and 113.64 minutes, biomass loading ratio to solvent of $1: 10 ; 1: 15 ; 1: 20 ; 1: 25$ and 1:30. Cocoa pod husks that have been pretreated was then separated into different phase: solid phase and liquid phase by using a vacuum filter. Solid phase was washed with distilled water until a neutral $\mathrm{pH}$ and drying in the oven at temperature of $105^{\circ} \mathrm{C}$ for 6 hours.

The chemical pre-treatment with $\mathrm{NaOH}$ was optimized by varying the concentrations of $\mathrm{NaOH}(4-8 \%(\mathrm{w} / \mathrm{v})$, centre point: $6 \%$ ), reaction time (60-100 minutes, centre point: 80 minutes) and ratio of biomass to solvent (1:15-1:25, centre point 1:20 w/v).

Alkaline peroxide pre-treatment- $5 \mathrm{~g}$ of 20 mesh-sized solids were transferred into $100 \mathrm{ml}$ flasks containing $100 \mathrm{ml}$ of alkaline peroxide solutions at $\mathrm{pH}$ 11.5. Flask were placed in an orbital shaker at a speed range of $180 \mathrm{rpm}$ and pretreated until desired retention time has been reached. At the end of the retention time flasks were removed from the shaker and the solid and liquid fractions were filtered through $10 \mu \mathrm{m}$ pore-sized filters. The solid fractions were washed with de-ionized water until they reached neutral $\mathrm{pH}$. After washing, the solid samples were dried in an oven at $50{ }^{\circ} \mathrm{C}$ for $48 \mathrm{~h}$ and used as feedstockd for hydrolysis.

The chemical pre-treatment with alkaline peroxide $\mathrm{H}_{2} \mathrm{O}_{2}$ was optimized by varying the concentrations of $\mathrm{H}_{2} \mathrm{O}_{2}(4-7 \% \mathrm{w} / \mathrm{v}$, centre point $5.5 \%(\mathrm{w} / \mathrm{v}))$, reaction time (40-90 minutes, centre point: 65 minutes), and ratio of biomass/solvent (4-7\% w/v).

Sulfuric acid pre-treatment- Sulfuric acid pre-treatment was performed in an autoclave at $121^{\circ} \mathrm{C}$. After autoclave the remaining solid residues were separated by vacuum filtration using $10 \mu \mathrm{m}$ pore-sized filters and the solid fractions washed with de-ionized water until they reached neutral $\mathrm{pH}$. Solid recovery yield was calculated as dry weight of water 
insoluble solid remaining after pre-treatment referred to 100 $\mathrm{g}$ of untreated raw material.

The chemical pre-treatment with $\mathrm{H}_{2} \mathrm{SO}_{4}$ was optimized by varying the concentrations of $\mathrm{H}_{2} \mathrm{SO}_{4}(0.5-1.5 \% \mathrm{w} / \mathrm{v}$, centre point: $1.0 \% \mathrm{w} / \mathrm{v})$, reaction time (60-120 minutes, centre point: 90 minutes), and ratio of biomass to solvent $(1: 4-1: 6 \mathrm{w} / \mathrm{v}$, centre point $1: 5 \mathrm{w} / \mathrm{v})$.

\section{Hydrolysis}

Sulphuric acid pre-treatment was performed in an autoclave at $121{ }^{\circ} \mathrm{C}$. Put 3 grams sample into $250 \mathrm{ml}$ Erlenmeyer and added a solution of $\mathrm{H} 2 \mathrm{SO} 43 \%$ with the ratio of biomass to solvent $(1: 10)$ for 2 hours. After that, the liquid phase of hydrolysis reaction result was separated from the solid phase. The liquid phase was used to test reducing sugar and total sugar.

\section{E. Experimental Design}

The experimental design selected for this study is a central composite design (CCD) that helps in investigating linear, quadratic, cubic and cross-product effects of the three pre-treatment process variables (independent) on the content of lignin and sugar (response). The three pre-treatment process variables studied are solvent concentration, reaction time, ratio of solid biomass to solvent. Each response of the pre-treatment process was used to develop a mathematical model that correlates the delignified lignin and sugar content to the pre-treatment process variables studied through first order, second order and interaction terms, according to the following second order polynomial equation,

$$
\mathrm{y}=\beta_{O}+\sum_{j=1}^{3} \beta_{i} X_{i}+\sum_{i j=1}^{3} \beta_{i j} X_{i} X_{j}+\sum_{j=1}^{3} \beta_{j j} X_{j}^{2}
$$

where $y$ is the predicted yield of response, $x i$ and $x j$ represent the variables or parameters $\beta o$ is the offset term $\beta j$ is the linear effect, $B \mathrm{ij}$ is first order interaction effect, $\beta \mathrm{jj}$ is a squared effect.

\section{F. Model fitting and statistical analysis}

Design Expert software version 7 (STAT-Ease Inc., Minneapolis, USA) was used for regression analysis of the experimental data to fit the second order polynomial equation and also for evaluation of the statistical significance of the equation developed.

\section{G. Analysis method}

Determination of pre-treated lignin after pre-treatment [18]. The isolation of lignin from black liquor was performed using precipitation method using $\mathrm{H}_{2} \mathrm{SO}_{4}$. The first step, of black liquor was diluted using aquades with a ratio (1: 2). Then stirring using a stirrer using $\mathrm{H}_{2} \mathrm{SO}_{4} \quad 20 \%$ solution until the $\mathrm{pH}$ of the solution to became 2 and heating to a temperature of $60^{\circ}$ with hot magnetic stirrer. After titration, allow at least 8 hours in order lignin completely precipitated. After lignin precipitated, it is filtered with filter paper and dried in an oven at a temperature of 50-60 ${ }^{\circ} \mathrm{C}$ for 24 hours and then weighed.

\section{Lignin weight (g) \\ Lignin $(\%)=\frac{\text { Cocoa pod husk weight }(g)}{\text { g) }}$}

Determination of precipitated lignin after hydrolysis-The lignin content in samples after hydrolysis was measured using TAPPI-Standard T 13 m-54.

Estimation of sugars- Total sugars in the filtrate were determined by the method of Dubois et al. [19] and reducing sugars in the filtrate were estimated by using 3,5 dinitrosalysilic acid method [20].

\section{RESULT AND DISCUSSION}

\section{A. Optimization of Sodium Hidroxide Pre-treatment}

The experimental design matrix and effect of effects of sodium hydroxide pre-treatment of CPHs at different sodium hydroxide concentration, reaction time and solid loading in solvent is shown in Table II.

TABLE II

EFFECTS OF SODIUM HYDROXIDE PRE-TREATMENT OF CPH AT DIFFERENT SODIUM HydroXide CONCENTRATION, REACTION TIME AND SOLID LOADING RATIO TO SOLVENT

\begin{tabular}{|c|c|c|c|c|c|c|c|}
\hline \multirow{2}{*}{ Run } & \multirow{2}{*}{$\begin{array}{c}\mathrm{NaOH} \\
(\%)\end{array}$} & \multirow{2}{*}{$\begin{array}{l}\text { Reaction } \\
\text { time } \\
\text { (minutes) }\end{array}$} & \multirow{2}{*}{$\begin{array}{c}\text { Biomass } \\
\text { Loading } \\
\text { in } \\
\text { Sovent }\end{array}$} & \multicolumn{2}{|c|}{ Lignin* } & \multirow{2}{*}{$\begin{array}{c}\text { Reducing } \\
\text { Sugar }\end{array}$} & \multirow{2}{*}{$\begin{array}{l}\text { Tota } \\
\text { suga }\end{array}$} \\
\hline & & & & I & II & & \\
\hline 1 & 4 & 60.00 & $1: 15$ & 11.65 & 22.80 & 5.19 & 8.39 \\
\hline 2 & 8 & 60.00 & $1: 15$ & 13.9 & 20.53 & 5.14 & 7.51 \\
\hline 3 & 4 & 100.00 & $1: 15$ & 11.7 & 22.76 & 10.69 & 11.21 \\
\hline 4 & 8 & 100.00 & $1: 15$ & 16 & 18.43 & 5.09 & 6.79 \\
\hline 5 & 4 & 60.00 & $1: 25$ & 15.97 & 18.49 & 8.18 & 8.44 \\
\hline 6 & 8 & 60.00 & $1: 25$ & 15.01 & 17.88 & 4.73 & 6.8 \\
\hline 7 & 4 & 100.00 & $1: 25$ & 16.18 & 18.23 & 12.94 & 13.59 \\
\hline 8 & 8 & 100.00 & $1: 25$ & 16.68 & 17.61 & 4.88 & 7.42 \\
\hline 9 & 2.64 & 80.00 & $1: 20$ & 11.55 & 22.72 & 9.31 & 11.37 \\
\hline 10 & 9.36 & 80.00 & $1: 20$ & 17.01 & 16.27 & 5.26 & 6.41 \\
\hline 11 & 6 & 46.36 & $1: 20$ & 14.42 & 19.96 & 4.09 & 9.26 \\
\hline 12 & 6 & 113.64 & $1: 20$ & 14.26 & 20.15 & 5.89 & 8.51 \\
\hline 13 & 6 & 80.00 & $1: 11.59$ & 10.87 & 23.72 & 5.74 & 7.55 \\
\hline 14 & 6 & 80.00 & $1: 28.41$ & 14.11 & 20.21 & 6.28 & 7.28 \\
\hline 15 & 6 & 80.00 & $1: 20$ & 12.8 & 21.7 & 6.76 & 10.02 \\
\hline 16 & 6 & 80.00 & $1: 20$ & 12.67 & 21.81 & 6.68 & 9.38 \\
\hline 17 & 6 & 80.00 & $1: 20$ & 12.15 & 22.25 & 6.61 & 9.71 \\
\hline
\end{tabular}

*) I Precipitated lignin after Pre-treatment

II Lignin content after Hydrolysis

Lignin is a chemical component contained in a plant. It is not soluble in most organic solvents. Lignin which protects the cellulose is resistant to hydrolysis since there is aryl alkyl bonds and ether bond [21]. Lignin in cocoa pod sample will inhibit the enzymatic or acid hydrolysis process to convert cellulose into simple sugars. Therefore it is necessary to do a pre-treatment process (delignification) using sodium hydroxide $(\mathrm{NaOH})$. Pre-treatment increased the effectiveness of cellulose hydrolysis and improve the enzymatic digestibility of biomass for fermentable sugars [10].

As seen in Table II, amount of sugars leaving the raw material and entering the liquid fraction changed with respect to the pre-treatment condition [10, 22]. Increasing biomass loading in solvent resulted in decrease especially in precipited lignin and decrease lignin content which remains in biomass [Table II]. 
Application and Selection of RSM Model- RSM is used to determine the appropriate model in predicting response. The model obtained is used to predict the response levels of precipitated lignin, the lignin content remains after hydrolysis, reducing sugar and total sugar content. The process of selecting the model is based on the description sequential model of sum of square, lack of fit test, and a summary of the model (model summary statistics) and test the statistical base (R-squared) [23]. Table III are presented the analysis of variance of response surface models.

TABLE III

ANALYSIS OF VARIANCE RESPONSE SURFACE MODEL

\begin{tabular}{|l|c|c|c|c|}
\hline \multirow{2}{*}{ Source of variance } & \multicolumn{3}{|c|}{ P values Prob < F } \\
\cline { 2 - 5 } & $\begin{array}{c}\text { Precipitated } \\
\text { Lignin }^{1}\end{array}$ & $\begin{array}{c}\text { Lignin } \\
\text { Content }^{1}\end{array}$ & $\begin{array}{c}\text { Reducing } \\
\text { Sugar }^{2}\end{array}$ & $\begin{array}{c}\text { Total } \\
\text { Sugar }^{3}\end{array}$ \\
\hline Model & $0.0099^{\mathrm{s}}$ & $0.0065^{\mathrm{s}}$ & $0.0017^{\mathrm{s}}$ & $0.0048^{\mathrm{s}}$ \\
\hline $\begin{array}{l}\text { A-NaOH } \\
\text { concentration }\end{array}$ & 0.0037 & 0.0015 & 0.0003 & 0.0004 \\
\hline B-Reaction Time & 0.3277 & 0.5482 & 0.013 & 0.134 \\
\hline $\begin{array}{l}\text { C-Biomass loading } \\
\text { ratio to solvent }\end{array}$ & 0.0028 & 0.0018 & 0.240 & 0.650 \\
\hline AB & 0.2404 & 0.4915 & 0.013 & 0.026 \\
\hline AC & 0.0374 & 0.1017 & 0.114 & 0.437 \\
\hline BC & 0.9242 & 0.5900 & 0.876 & 0.264 \\
\hline $\mathrm{A}^{2}$ & 0.0265 & 0.0105 & & \\
\hline $\mathrm{B}^{2}$ & 0.0239 & 0.0262 & & \\
\hline $\mathrm{C}^{2}$ & 0.5654 & 0.5396 & & $0.0664^{\mathrm{ns}}$ \\
\hline Lack of Fit $^{2}$ & $0.0509^{\mathrm{ns}}$ & $0.0879^{\mathrm{ns}}$ & $0.0531^{\mathrm{ns}}$ & \\
\hline $\mathrm{R}^{2}$ & 0.91 & 0.90 & 0.84 & 0.80 \\
\hline s) & \multicolumn{3}{|c|}{}
\end{tabular}

${ }^{\mathrm{s})}$ significant ${ }^{\mathrm{ns})}$ non-significant

${ }^{1)}$ after pre-treatment; ${ }^{2)}$ after hydrolysis

Response Surface Optimization - Table IV outlines optimization criteria of variables and responses which will be optimized in this study. It can be seen the goal and importance level of each variable and the response to get the solution from variables that produces the optimal response.

TABLE IV

OPTIMIZATION CRITERIA OF VARIABLES AND RESPONSES

\begin{tabular}{|l|c|c|c|c|}
\hline \multicolumn{1}{|c|}{ Criteria } & Goal & $\begin{array}{c}\text { Upper } \\
\text { level }\end{array}$ & $\begin{array}{c}\text { Lower } \\
\text { level }\end{array}$ & $\begin{array}{c}\text { The } \\
\text { importance } \\
\text { level }\end{array}$ \\
\hline $\begin{array}{l}\text { Concentration } \\
\text { NaOH(\%) }\end{array}$ & In range & 4 & 8 & $3(+++)$ \\
\hline $\begin{array}{l}\text { Reaction Time } \\
\text { (minutes) }\end{array}$ & In range & 60 & 100 & $3(+++)$ \\
\hline $\begin{array}{l}\text { biomass loading } \\
\text { ratio to solvent (\%) }\end{array}$ & In range & 15 & 25 & $3(+++)$ \\
\hline $\begin{array}{l}\text { Precipitated lignin } \\
\text { after pre-treatment } \\
(\%)\end{array}$ & maximize & 10.87 & 17.01 & $3(+++)$ \\
\hline $\begin{array}{l}\text { Lignin content } \\
\text { remains after } \\
\text { hydrolysis (\%) }\end{array}$ & minimize & 16.27 & 23.72 & $3(+++)$ \\
\hline $\begin{array}{l}\text { Reducing Sugar } \\
(\%)\end{array}$ & maximize & 4.09 & 12.94 & $3(+++)$ \\
\hline Total sugar (\%) & maximize & 6.41 & 13.59 & $3(+++)$ \\
\hline
\end{tabular}

Variables such as $\mathrm{NaOH}$ concentration, reaction time, and the ratio of biomass to solvent is optimized with the goal (target component) in range with the important level 3 (+++). This is due to the possibility of an optimal response is not generated at a central point, but there is the suggested specified value other than central point. In this study, the response of precipitated lignin, total lignin, reducing sugar and total sugar goal is set as maximize because from the delignification process is expected to accrue a maximum precipitated lignin, with maximal reducing sugar and total sugar. while the remaining lignin content expected to be minimal.

After all the variables and the response is determined of its important level and its goal, the program will analyze the optimum solution by looking at the value of desirability. The optimal solution is obtained after being processed by the Design Expert 7 can be seen in Table V.

TABLE V

Optimal SOlution ACCORding To DESIGN EXPERT 7 SOFTWARE

\begin{tabular}{|c|c|c|c|c|c|c|c|}
\hline $\begin{array}{c}\text { Concentra } \\
\text { tion } \\
\text { NaOH } \\
(\%)\end{array}$ & $\begin{array}{c}\text { Reaction } \\
\text { Time } \\
\text { (minutes) }\end{array}$ & $\begin{array}{c}\text { Biomass } \\
\text { loading } \\
\text { ratio to } \\
\text { solvent }(\%)\end{array}$ & $\begin{array}{c}\text { Precipitat } \\
\text { ed lignin } \\
(\%)\end{array}$ & $\begin{array}{c}\text { Lignin } \\
(\%)\end{array}$ & $\begin{array}{c}\text { Reducing } \\
\text { sugar } \\
(\%)\end{array}$ & $\begin{array}{c}\text { Total } \\
\text { sugar (\%) }\end{array}$ & $\begin{array}{c}\text { Desira } \\
\text { bility }\end{array}$ \\
\hline 4 & 100 & 25 & 15.03 & 19.58 & 11.75 & 12.77 & 0.73 \\
\hline 4 & 99.99 & 24.96 & 15.01 & 19.60 & 11.74 & 12.77 & 0.73 \\
\hline 4.04 & 100 & 25 & 15.01 & 19.60 & 11.67 & 12.72 & 0.73 \\
\hline
\end{tabular}

Based on the optimization solution analysis by DesignExpert 7 Software it was found that there were three desirability value displayed Table IX. Desirability intended to reach the value of 1.0. The treatment chosen as an optimum treatment solution by Design-Expert 7 Software is seen in the first solution where $\mathrm{NaOH}$ concentration factor $\left(\mathrm{X}_{1}\right)$ showed a concentration of $4.00 \%$, and the reaction time $\left(\mathrm{X}_{2}\right) 100$ minutes, biomass ratio to solvent $\left(\mathrm{X}_{3}\right)$ of 1: 25 with the desirability of 0.974 . These results match with the results from verification in laboratory.

\section{B. Optimization of Alkali Peroxide Pre-treatment}

The design of Pre-treatment Process Optimization-The experimental design matrix and effect of alkaline peroxide pre-treatment of $\mathrm{CPHs}$ at different sodium peroxide concentration, reaction time and solid loading in solvent is shown in Table VI. Amount of sugars leaving the raw material and entering the liquid fraction changed with respect to the pre-treatment condition.

TABLE VI

EFFECTS OF ALKALINE PEROXIDE PRE-TREATMENT OF RICE STRAW AT DIFFERENT HYDROHEN PEROXIDE CONCENTRATION, REACTION TIME, AND SOLID LOADING RATIO TO SOLVENT

\begin{tabular}{|l|l|l|l|l|l|l|l|}
\hline STD & $\begin{array}{c}\mathrm{H}_{2} \mathrm{O}_{2} \\
(\%)\end{array}$ & $\begin{array}{c}\text { Reaction } \\
\text { Time } \\
(\text { minutes) }\end{array}$ & $\begin{array}{c}\text { Ratio of } \\
\text { Biomass } \\
\text { loading } \\
(\%)\end{array}$ & $\begin{array}{c}\text { Precipitated } \\
\text { Lignin }(\%)\end{array}$ & $\begin{array}{c}\text { Lignin } \\
\text { Content } \\
(\%)\end{array}$ & $\begin{array}{c}\text { Reducing } \\
\text { Sugar } \\
(\%)\end{array}$ & $\begin{array}{c}\text { Total } \\
\text { Sugar } \\
(\%)\end{array}$ \\
\hline 1 & 4 & 40 & 4 & 11 & 22.9 & 5.28 & 12.97 \\
\hline 2 & 7 & 40 & 4 & 10.5 & 24.29 & 6.71 & 8.97 \\
\hline 3 & 4 & 90 & 4 & 11.47 & 23.35 & 5.04 & 6.47 \\
\hline 4 & 7 & 90 & 4 & 10.04 & 24.85 & 5.61 & 7.51 \\
\hline 5 & 4 & 40 & 7 & 9.86 & 24.8 & 4.44 & 7.55 \\
\hline 6 & 7 & 40 & 7 & 6.86 & 27 & 10.91 & 12.77 \\
\hline 7 & 4 & 90 & 7 & 8.43 & 26.36 & 7.21 & 10.03 \\
\hline 8 & 7 & 90 & 7 & 7 & 27.7 & 9.39 & 11.23 \\
\hline 9 & 2.98 & 65 & 5.5 & 9.69 & 25.25 & 3.34 & 9.02 \\
\hline 10 & 8.02 & 65 & 5.5 & 6.73 & 27 & 6.89 & 11.02 \\
\hline 11 & 5.5 & 22.96 & 5.5 & 7.64 & 26.34 & 6.49 & 8.59 \\
\hline 12 & 5.5 & 107.04 & 5.5 & 7.27 & 25.92 & 5.94 & 5.71 \\
\hline 13 & 5.5 & 65 & 2.98 & 13.09 & 21.5 & 4.61 & 16.26 \\
\hline 14 & 5.5 & 65 & 8.02 & 8.48 & 23.76 & 11.18 & 15.06 \\
\hline 15 & 5.5 & 65 & 5.5 & 9.93 & 24.33 & 5.33 & 8.14 \\
\hline 16 & 5.5 & 65 & 5.5 & 9.71 & 25 & 5.99 & 7.19 \\
\hline 17 & 5.5 & 65 & 5.5 & 9.11 & 24.83 & 6.46 & 7.21 \\
\hline
\end{tabular}

Application and Selection the Models- Table VII presented the analysis of variance of response surface models. From Table VII it can be seen that the mathematical model for the all observed response surface is significant. $\mathrm{H}_{2} \mathrm{O}_{2}$ concentration significantly affected the precipitated of lignin, the lignin content, reducing sugar and total lignin. 
Ration of biomass loading in solvent affected significantly precipitated lignin, the lignin content remains after hydrolysis, reducing sugar and total sugars.

TABLE VII

ANALYSIS OF VARIANCE RESPONSE SURFACE MODEL

\begin{tabular}{|c|c|c|c|c|}
\hline \multirow{2}{*}{$\begin{array}{l}\text { Source of } \\
\text { Variance }\end{array}$} & \multicolumn{4}{|c|}{$P$ values Prob $<F$} \\
\hline & $\begin{array}{l}\text { Precipitated } \\
\text { Lignin }^{1}\end{array}$ & $\begin{array}{c}\text { Lignin } \\
\text { Content }^{1}\end{array}$ & $\begin{array}{l}\text { Reducing } \\
\text { sugar }^{2}\end{array}$ & Total Sugar $^{3}$ \\
\hline Model & $0.0008^{*}$ & $0.0031^{*}$ & $0.0024^{*}$ & $0.0434^{*}$ \\
\hline $\begin{array}{l}\text { A- } \\
\text { Concentrati } \\
\text { on of } \mathrm{H}_{2} \mathrm{O}_{2}\end{array}$ & $0.0012^{*}$ & $0.0062^{*}$ & $0.0011^{*}$ & 0.3482 \\
\hline $\begin{array}{l}\text { B-Reaction } \\
\text { Time }\end{array}$ & 0.4102 & 0.3258 & 0.7543 & 0.1772 \\
\hline $\begin{array}{l}\text { C-Biomass } \\
\text { loading ratio } \\
\text { to solvent }\end{array}$ & $<0.0001^{* * *}$ & $0.0006^{* *}$ & $0.0003^{* * *}$ & 0.6081 \\
\hline $\mathrm{AB}$ & 0.7117 & 0.6983 & 0.0678 & 0.8499 \\
\hline $\mathrm{AC}$ & 0.1764 & 0.7366 & $0.0271^{*}$ & 0.1139 \\
\hline $\mathrm{BC}$ & 0.4599 & 0.5224 & 0.3138 & 0.1303 \\
\hline $\mathrm{A}^{2}$ & 0.0880 & 0.0287 & 0.4497 & 0.3717 \\
\hline $\mathrm{B}^{2}$ & 0.0099 & 0.0284 & 0.4796 & 0.5816 \\
\hline $\mathrm{C}^{2}$ & 0.0147 & 0.0090 & 0.0171 & 0.0025 \\
\hline Lack of Fit & $0.3318^{\text {ns }}$ & $0.1891^{\text {ns }}$ & $0.2926^{\mathrm{ns}}$ & $0.0612^{\mathrm{ns}}$ \\
\hline $\mathrm{R}^{2}$ & 0.9526 & 0.9278 & 0.9331 & 0.8336 \\
\hline
\end{tabular}

${ }^{\text {s) }}$ significant ${ }^{\mathrm{ns})}$ non-significant $*$ significant $* *$ very significant

${ }^{1)}$ after pre-treatment; ${ }^{2)}$ after hydrolysis

Response Surface Optimization-Table VIII outlines optimization criteria of variables and responses which will be optimized in this study. It can be seen the goal and importance level of each variable and the response to get the solution from variables that produces the optimal response.

TABLE VIII

OPTIMIZATION CRITERIA OF VARIABLES AND RESPONSES

\begin{tabular}{|l|c|c|c|c|}
\hline \multicolumn{1}{|c|}{ Criteria } & Goal & $\begin{array}{c}\text { Lower } \\
\text { level }\end{array}$ & $\begin{array}{c}\text { Upper } \\
\text { level }\end{array}$ & $\begin{array}{c}\text { The importance } \\
\text { level }\end{array}$ \\
\hline $\begin{array}{l}\text { Concentration } \\
\mathrm{H}_{2} \mathrm{O}_{2}(\%)\end{array}$ & In range & 4 & 8 & $3(+++)$ \\
\hline $\begin{array}{l}\text { Reaction Time } \\
\text { (minutes) }\end{array}$ & In range & 60 & 100 & $3(+++)$ \\
\hline $\begin{array}{l}\text { Ratio biomass } \\
\text { loading to solvent }\end{array}$ & In range & 15 & 25 & $3(+++)$ \\
\hline $\begin{array}{l}\text { Precipatated } \\
\text { lignin (\%) }\end{array}$ & maximize & 6.72 & 13.09 & $3(+++)$ \\
\hline $\begin{array}{l}\text { Lignin content } \\
\text { after hydrolysis } \\
(\%)\end{array}$ & minimize & 21.5 & 11.18 & $3(+++)$ \\
\hline $\begin{array}{l}\text { Reducing sugar } \\
(\%)\end{array}$ & maximize & 334 & 12.94 & $3(+++)$ \\
\hline Total sugar (\%) & maximize & 6.47 & 16.26 & $3(+++)$ \\
\hline
\end{tabular}

Variables such as $\mathrm{H} 2 \mathrm{O} 2$ concentration, reaction time, and the ratio of biomass to solvent is optimized with the goal (target component) in range with the important level $3(+++)$. This is due to the possibility of an optimal response is not generated at a central point, but there is the suggested specified value other than central point. In this study, the response of precipitated lignin, total lignin, reducing sugar and total sugar goal is set as maximize because from the delignification process is expected to accrue a maximum precipitated lignin, with maximal reducing sugar and total sugar, while the remaining lignin content expected to be minimal.

After all the variables and the response is determined of its important level and its goal, the program will analyse the optimum solution by looking at the value of desirability. The optimal solution is obtained after being processed by the Design Expert 7 can be seen in Table IX.

TABLE IX

OPTIMAL SOLUTION ACCORDING TO DESIGN EXPERT 7 SOFTWARE

\begin{tabular}{|c|c|c|c|c|c|c|c|}
\hline $\begin{array}{c}\mathrm{H}_{2} \mathrm{O}_{2} \\
(\%)\end{array}$ & $\begin{array}{c}\text { Reaction } \\
\text { Time } \\
(\text { minutes })\end{array}$ & $\begin{array}{c}\text { Ratio } \\
\text { Biomass/s } \\
\text { olvent } \\
(\%)\end{array}$ & $\begin{array}{c}\text { Precipit } \\
\text { ated } \\
\text { lignin } \\
(\%)\end{array}$ & $\begin{array}{c}\text { Lignin } \\
\text { Conte } \\
\text { nt } \\
(\%)\end{array}$ & $\begin{array}{c}\text { Reduc } \\
\text { ing } \\
\text { Sugar } \\
(\%)\end{array}$ & $\begin{array}{c}\text { Total } \\
\text { Sugar } \\
(\%)\end{array}$ & $\begin{array}{c}\text { Desira } \\
\text { bility }\end{array}$ \\
\hline 5.52 & 61.97 & 7.00 & 8.759 & 25.03 & 8.17 & 10.37 & 0.508 \\
\hline 5.56 & 62.46 & 7.00 & 8.726 & 25.02 & 8.23 & 10.42 & 0.508 \\
\hline 5.60 & 61.79 & 7.00 & 8.700 & 25.07 & 8.26 & 10.46 & 0.507 \\
\hline
\end{tabular}

Based on the optimization solution analysis by DesignExpert 7 Software it was found that there were three desirability value displayed Table IX. Desirability intended to reach 1.0. The treatment chosen as an optimum treatment solution is by Design-Expert 7 Software which shows some of the factors that influence, seen in the first solution $\mathrm{H}_{2} \mathrm{O}_{2}$ concentration factor $\left(\mathrm{X}_{1}\right)$ showed a concentration of $5.52 \%$, and the reaction time $\left(\mathrm{X}_{2}\right) 61.97$ minutes, ratio of biomass to solvent $\left(\mathrm{X}_{3}\right) 7 \%$ with the desirability of 0.974 . These results match with the results from verification in laboratory.

\section{Optimization of Sulfuric Acid Pre-treatment}

The experimental design matrix and effect of effects of alkaline peroxide pre-treatment of $\mathrm{CPH}$ at different sodium peroxide concentration, reaction time and solid loading in solvent is shown in Table X. Amount of sugars leaving the raw material and entering the liquid fraction changed with respect to the pre-treatment condition.

Application and Selection the Models- Table XI presented the analysis of variance of response surface models. From Table XI it can be seen that the mathematical model for the all observed response surface is significant. $\mathrm{H}_{2} \mathrm{SO}_{4}$ concentration significantly affected the precipitated of lignin, the lignin content, reducing sugar and total lignin. Ration of biomass loading in solvent affected significantly precipitated lignin, the lignin content remains after hydrolysis, reducing sugar and total sugars.

TABLE X

EFFECTS OF ALKALINE PEROXIDE PRE-TREATMENT OF RICE STRAW AT DIFFERENT HYDROHEN PEROXIDE CONCENTRATION, REACTION TIME, AND SOLID LOADING RATIO TO SOLVENT

\begin{tabular}{|l|l|l|l|l|c|c|}
\hline STD & $\begin{array}{c}\mathrm{H}_{2} \mathrm{SO}_{4} \\
(\%)\end{array}$ & $\begin{array}{c}\text { Reaction } \\
\text { Time } \\
(\text { minutes })\end{array}$ & $\begin{array}{c}\text { Ratio } \\
\text { Biomass/solvent } \\
(\%)\end{array}$ & $\begin{array}{c}\text { Total } \\
\text { Sugar } \\
(\%)\end{array}$ & $\begin{array}{c}\text { Reducing } \\
\text { Sugar } \\
(\%)\end{array}$ & $\begin{array}{c}\text { Lignin } \\
\text { Content } \\
(\%)\end{array}$ \\
\hline 1 & 0.50 & 60.00 & 4.00 & 7.40 & 5.30 & 33.03 \\
\hline 2 & 1.50 & 60.00 & 4.00 & 9.96 & 7.69 & 28.99 \\
\hline 3 & 0.50 & 120.00 & 4.00 & 9.27 & 6.77 & 31.85 \\
\hline 4 & 1.50 & 120.00 & 4.00 & 14.62 & 6.41 & 31.98 \\
\hline 5 & 0.50 & 60.00 & 6.00 & 11.63 & 10.21 & 23.93 \\
\hline 6 & 1.50 & 60.00 & 6.00 & 18.85 & 16.32 & 19.20 \\
\hline 7 & 0.50 & 120.00 & 6.00 & 13.96 & 11.85 & 23.09 \\
\hline 8 & 1.50 & 120.00 & 6.00 & 19.92 & 11.70 & 22.97 \\
\hline 9 & 0.16 & 90.00 & 5.00 & 6.00 & 5.20 & 32.88 \\
\hline 10 & 1.84 & 90.00 & 5.00 & 18.85 & 16.74 & 19.77 \\
\hline 11 & 1.00 & 39.55 & 5.00 & 8.96 & 6.75 & 31.32 \\
\hline 12 & 1.00 & 140.45 & 5.00 & 14.99 & 12.51 & 21.88 \\
\hline 13 & 1.00 & 90.00 & 3.32 & 9.34 & 7.20 & 28.28 \\
\hline 14 & 1.00 & 90.00 & 6.68 & 16.56 & 14.13 & 20.34 \\
\hline 15 & 1.00 & 90.00 & 5.00 & 16.17 & 14.67 & 20.81 \\
\hline 16 & 1.00 & 90.00 & 5.00 & 15.06 & 13.05 & 21.45 \\
\hline 17 & 1.00 & 90.00 & 5.00 & 14.77 & 11.54 & 23.41 \\
\hline
\end{tabular}


TABLE XI

ANALYSIS OF VARIANCE RESPONSE SURFACE MODEL

\begin{tabular}{|l|c|c|c|}
\hline \multirow{2}{*}{ Source of Variance } & \multicolumn{3}{|c|}{ Value of P Prob < F } \\
\cline { 2 - 4 } & $\begin{array}{c}\text { Lignin remains } \\
\text { in biomass }\end{array}$ & $\begin{array}{c}\text { Reducing } \\
\text { sugar }\end{array}$ & Total Sugar \\
\hline Model & 0.0040 & 0.0034 & $<0.0001$ \\
\hline $\begin{array}{l}\mathrm{A}-\text { Concentration of } \\
\mathrm{H}_{2} \mathrm{SO}_{4}\end{array}$ & 0.0313 & 0.0128 & $<0.0001$ \\
\hline B-Reaction Time & 0.3987 & 0.4811 & 0.0048 \\
\hline $\begin{array}{l}\text { C-Biomass ratio to } \\
\text { solvent }\end{array}$ & 0.0018 & 0.0024 & $<0.0001$ \\
\hline Lack of Fit & 0.1235 & 0.2762 & 0.1666 \\
\hline $\mathrm{R}^{2}$ & 0.6280 & 0.6377 & 0.8840 \\
\hline
\end{tabular}

Response Surface Optimization-Table XII outlines optimization criteria of variables and responses which will be optimized in this study. It can be seen the goal and importance level of each variable and the response to get the solution from variables that produces the optimal response

TABLE XII

DESCRIPTION OF VARIABLES AND RESPONSES OF OPTIMIZATION PROCESS

\begin{tabular}{|l|c|c|c|c|}
\hline \multicolumn{1}{|c|}{ Criteria } & Goal & $\begin{array}{c}\text { Lower } \\
\text { Level }\end{array}$ & $\begin{array}{c}\text { Upper } \\
\text { Level }\end{array}$ & $\begin{array}{c}\text { The Importance } \\
\text { Level }\end{array}$ \\
\hline $\begin{array}{l}\text { Concentration } \\
\mathrm{H}_{2} \mathrm{SO}_{4}(\%)\end{array}$ & In range & 0.5 & 1.5 & $3(+++)$ \\
\hline $\begin{array}{l}\text { Reaction Time } \\
\text { (minutes) }\end{array}$ & In range & 60 & 120 & $3(+++)$ \\
\hline $\begin{array}{l}\text { Ratio biomass } \\
\text { loading to solvent }\end{array}$ & Maximize & 4 & 6 & $3(+++)$ \\
\hline Total sugar (\%) & Maximize & 6.00 & 19.92 & $3(+++)$ \\
\hline Reducing sugar (\%) & Maximize & 5.20 & 16.74 & $3(+++)$ \\
\hline $\begin{array}{l}\text { Lignin content } \\
\text { remain in biomass. } \\
(\%)\end{array}$ & Minimize & 19.2 & 33.03 & $3(+++)$ \\
\hline
\end{tabular}

Based optimization solution analysis by Design-Expert 7 Software it was found that there were three desirability value displayed Table XIII. Desirability intended to reach 1.0. The treatment chosen as an optimum treatment solution is by Design-Expert 7 Software which shows some of the factors that influence, seen in the first solution $\mathrm{H}_{2} \mathrm{SO}_{4}$ concentration factor $\left(\mathrm{X}_{1}\right)$ showed a concentration of $1.50 \%$, and the reaction time $\left(\mathrm{X}_{2}\right) 120$ minutes, ratio of biomass to solvent $\left(\mathrm{X}_{3}\right) 6 \%$ with the desirability of 0.974 . These results match with the results from verification in laboratory.

TABLE XIII

OPTIMAL SOLUTION ACCORDING TO DESIGN EXPERT 7 SOFTWARE

\begin{tabular}{|c|c|c|c|c|c|c|}
\hline $\begin{array}{c}\mathrm{H}_{2} \mathrm{SO}_{4} \\
(\%)\end{array}$ & $\begin{array}{c}\text { Reaction } \\
\text { Time } \\
(\text { minutes) }\end{array}$ & $\begin{array}{c}\text { Bimass } \\
\text { Loading } \\
\text { Ratio } \\
(\%)\end{array}$ & $\begin{array}{c}\text { Total } \\
\text { sugar } \\
(\%)\end{array}$ & $\begin{array}{c}\text { Reducing } \\
\text { Sugar } \\
(\%)\end{array}$ & $\begin{array}{c}\text { Lignin } \\
\text { remained in } \\
\text { biomass } \\
(\%)\end{array}$ & Desirability \\
\hline 1.50 & 120.00 & 6.00 & 20.49 & 15.60 & 18.87 & 0.974 \\
\hline 1.50 & 119.54 & 6.00 & 20.47 & 15.59 & 18.88 & 0.974 \\
\hline 1.49 & 120.00 & 6.00 & 20.41 & 15.54 & 18.92 & 0.973 \\
\hline
\end{tabular}

Based on the optimization solution analysis by DesignExpert 7 Software it was found that there were three desirability value displayed. Desirability intended to reach 1.0. The treatment chosen as an optimum treatment solution is by Design-Expert 7 Software which shows some of the factors that influence, seen in the first solution $\mathrm{H}_{2} \mathrm{SO}_{4}$ concentration factor $\left(\mathrm{X}_{1}\right)$ showed a concentration of $1.50 \%$, and the reaction time $\left(\mathrm{X}_{2}\right) 120.00$ minutes, biomass comparison with solvent $\left(\mathrm{X}_{3}\right) 6.00 \%$ with the desirability of 0,974 . These results match with the results from verification in laboratory.

\section{CONCLUSIONS}

The $\mathrm{NaOH}$ chemical pre-treatment was optimized by varying the concentrations of $\mathrm{NaOH}(4-8 \%(\mathrm{w} / \mathrm{v})$, centre point: $6 \%)$, reaction time (60-100 minutes, centre point: 80 minutes) and ratio of biomass to solvent (1:15-1:25, centre point 1:20 w/v). The optimum conditions in this study was at the concentration of $\mathrm{NaOH}\left(\mathrm{X}_{1}\right)$ of $4 \% \mathrm{w} / \mathrm{v}$, reaction time $\left(\mathrm{X}_{2}\right)$ of 100 minutes; ratio of biomass/solvent $\left(\mathrm{X}_{3}\right)$ of 1:25 $(\mathrm{w} / \mathrm{v})$. The lignin content after pre-treatment was $15.03 \%$ lignin, lignin content after hydrolysis was $19.57 \%, 11.75 \%$ of reducing sugar, and $12.78 \%$ of total sugar.

The chemical pre-treatment with alkaline peroxide $\left(\mathrm{H}_{2} \mathrm{O}_{2}\right)$ was optimized by varying the concentrations of $\mathrm{H}_{2} \mathrm{O}_{2}$ (4$7 \% \mathrm{w} / \mathrm{v}$, centre point $5.5 \%(\mathrm{w} / \mathrm{v}))$, reaction time $(40-90$ minutes, centre point: 65 minutes), and ratio of biomass/solvent $(4-7 \% \mathrm{w} / \mathrm{v})$. The optimum conditions in this study was at the concentration of $\mathrm{H}_{2} \mathrm{O}_{2}$ concentration $\left(\mathrm{X}_{1}\right)$ of $5.52 \% \mathrm{w} / \mathrm{v}$, reaction time $\left(\mathrm{X}_{2}\right)$ of 61.97 minutes, biomass loading in solvent $\left(\mathrm{X}_{3}\right) 7 \% \mathrm{w} / \mathrm{v}$. The lignin content after pretreatment was 8.76 , lignin content after hydrolysis was $25.03 \%, 8.17 \%$ of reducing sugar, and $10.37 \%$ of total sugar.

The chemical pre-treatment with $\mathrm{H}_{2} \mathrm{SO}_{4}$ was optimized by varying the concentrations of $\mathrm{H}_{2} \mathrm{SO}_{4} \quad(0.5-1.5 \%$ $\mathrm{w} / \mathrm{v})$, reaction time (60-120 minutes, centre point: 90 minutes), and ratio of biomass to solvent (1:4-1:6 w/v, centre point $1: 5 \mathrm{w} / \mathrm{v})$. The optimum conditions was reached without hydrolysis. The optimum condition this study is at the $\mathrm{H}_{2} \mathrm{SO}_{4}$ concentration $\left(\mathrm{X}_{1}\right)$ of $1.5 \%$, reaction time $\left(\mathrm{X}_{2}\right)$ of 120 minutes, ratio of biomass/solvent $\left(\mathrm{X}_{3}\right)$ of $6 \%$. The lignin content after pre-treatment was $18.8 \%, \quad 15.59 \%$ of reducing sugar and $20.49 \%$ of total sugar.

This research findings could serve as protocol for pretreatment process in further process design of bioethanol production process from cocoa pod husk using various solvent. Analysis of mass and material balance is important factor to study for practical application of this finding.

\section{ACKNOWLEDGMENT}

The authors would like to thank Directorate General of Higher Education of Republic of Indonesia for the PUPT Research Grant 2015.

\section{REFERENCES}

[1] S.K. Adzimah, E.K. Asian, E. K.. Design of Cocoa Pod Splitting Machine, Res. J. Appl. Sci. Eng. Technol., 2)4): 622 - 634, 2010. Maxwell Scientific Organization Pp. 16 - 25, 2010.

[2] M.Irfan, M. Gulsher, S. Abbas, Q. Syed, M. Nadeem. Effect of various pre-treatment conditions on enzymatic saccharification. Songklanakarin J. Sci. Technol. 33 (4), 397-404, Jul. - Aug. 2011

[3] C.E. Wyman, B.E. Dale, R.T Elander, M. Holtzapple, M.R. Ladisch MR, Y.Y. Lee .Coordinated development of leading biomass pretreatment technologies. Bioresour Technol. 96(18):1959-66. Epub Dec, 2005.

[4] C. A. Cardona, O. J. Sa'nchez.2007. Fuel ethanol production: Process design trendsand integration opportunities (review). Bioresource Technology 98, pp 2415-2457, 2007

[5] S.C. Rabelo, N.A.A. Fonseca, R.R. Andrade, R. Maciel Filho, A.C. Costa. 2011. Ethanol production from enzymatic hydrolysis of sugarcane bagasse pretreated with lime and alkaline hydrogen peroxide. Biomass Bioenergy., 25, pp. 2600-2607, 2011.

[6] M.J. Taherzadeh and K. Karimi. Pre-treatment of Lignocellulosic Wastes to Improve Ethanol and Biogas Production: A Review . J. Mol. Sci. 9, pp.1621-1651; DOI: 10.3390/ijms9091621, 2008. 
[7] Y. Sun and J. Cheng, .. 2002. Hydrolysis of Lignocellulosic Material for Ethanol Production : A review. Bioresource technology, vol.83, pp. 1-11, 2010.

[8] R.A. Silverstein, Y. Chen, R. R. Sharma-Shivappa, M.1 D. Boyette, J. Osborne. 2007. A comparison of chemical pre-treatment methods for improving saccharification of cotton stalks. Bioresource Technology 98, pp. 3000-3011, 2007.

[9] B. Qi, X. Chen, F. Shen,Y. Su, and Y. Wan,Optimization of Enzymatic Hydrolysis of Wheat Straw Pretreated by Alkaline Peroxide Using Response Surface Methodology. Ind. Eng. Chem. Res., 48, 7346-7353, 2009.

[10] J. Xu, J. J. Cheng, R.R. Sharma-Shivappa, and J. C. Burns. Sodium Hydroxide Pre-treatment of Switchgrass for Ethanol Production, Energy Fuels, 24, pp.2113-2119, 2001.

[11] D.P. Singh, and K.R. Trivedi. Acid and Alkaline Pre-treatment Of Lignocellulosic Biomass To Produce Ethanol As Biofuel. International Journal Of ChemTech Research 5 (2): 728-734, 2013.

[12] M. Carolina de Albuquerque Wanderleya, C.M. Martínb, G. J. de M. Rochad, E.R. Gouveiaa. Increase in ethanol production from sugarcane bagasse based on combined pre-treatments and fed-batch enzymatic hydrolysis. Bioresource Technology. Volume 128,pp: 448-453. 2013.

[13] Z.K. Daud, A.S.M., Aripin, A.M., Awang, H., Hatta, Z.M Composition and Morphological of Cocoa Pod Husks and Cassava Peels for Pulp and Paper Production. Australian Journal of Basic and Applied Science, 7(9), pp. 406-411, 2013

[14] O.O. Awolu, and S.O. Oyeyemi, Optimization of Bioethanol production from Coco (Theobroma cacao) Bean Shell Int.J.Curr.Microbiol.App.Sci 4(4): pp.506-514, 2015.
[15] L.K. Syam. Kajian Pemanfaatan Pod Kakao (Theobroma cacao) Melalui Hidrolisis Asam Lignoselulosa untuk Menghasilkan Etanol. [Skripsi]. Bogor: Fakultas Teknologi Pertanian, IPB. Bogor. 2000.

[16] L. C. Vriesmann, R.F.Teófilo, C.L. de Oliveira Petkowicz. Optimization of nitric acid-mediated extraction of pectin from cacao pod husks (Theobroma cacao L.) using response surface methodology Carbohydrate Polymers 84, pp:1230-1236, 2011.

[17] Chan., S.Y., Choo., W.S. Effect of Extraction Conditions on the Yield and Chemical Properties of Pectin from Cocoa Husks. Food Chemistry Volume 141, Issue 4 : pp:3752-3758, 2013

[18] H. Kim, M.K. Hill dan A.L. Fricke. Preparation of Kraft Lignin FromBlack Liquor. Tappi Journal 12 : pp;112-115, 1987.

[19] G.C. Miller, Use of the Dinitrosalicylic Acid Reagent for the Determination of Reducing Sugar. Analitical Chemist. 31: 420-428., 1959.

[20] M. Dubois, K.A. Gilles. J.K. Hamilton. JK, Rebers. PA, Amith.. Calorimetric Method for Determination of Sugars and Releated Substances. Anal Chem 28(3), pp: 350-356, 1956.

[21] J. Perez, J.Munoz-Dorado, J. de la Rubia, Biodegradation and Biological Treatments of Cellulose, Hemicelluloses, and Lignin : An Averview, int, Microbial, 5, pp.53-63, 2002.

[22] P. Karagöz, M. Özkan. Optimization of dilute acid and alkaline peroxide pre-treatment to enhance ethanol production from wheat straw. Turkish Journal of Biochemistry-Turk J Biochem. 2013; 38 (4) ;pp. 457-467. 2013.

[23] R.H Myers, and D.C. Montgomery, Response Surface Methodology: Process and Product Optimization Using Designed Experiments, New York: John Wiley \& Sons. 1995. 